\title{
RANCANG BANGUN APLIKASI PERCETAKAN TIGA BERSAUDARA BERBASIS WEB DENGAN METODE WATERFALL
}

\author{
Nawassyarif ${ }^{1}$, Yunanri. $\mathbf{W}^{2 *}$, Ardian Shalihin ${ }^{3}$ \\ 1,2,3 Teknik Informatika Universitas Teknologi Sumbawa \\ email: yunanri.w@uts.ac.id ${ }^{2 *}$
}

\begin{abstract}
Abstrak: Perkembangan teknologi yang sangat pesat dan fasilitas-fasilitas pendukung yang semakin banyak, masyarakat mulai menggunakan berbagai layanan yang bersifat komputerisasi karena lebih mudah dan banyak pilihan yang dapat mempermudah segala kebutuhan yang harus dipenuhi dan diselesaikan. Penelitian ini bertujuan untuk membangun aplikasi web. Aplikasi ini dibangun menggunakan bahasa pemrograman PHP dengan framework CodeIgniter, database MySql. Instrumen teknik pengumpulan data pada penelitian ini yaitu wawancara, studi pustaka dan observasi. Metode pengembangan perangkat lunak menggunakan metode waterfall yaitu analisis kebutuhan perangkat lunak, desain, pembuatan kode program dan pengujian. Serta metode pengujian perangkat lunak menggunakan pengujian black-box. Hasil akhir dari penelitian ini adalah Aplikasi Percetakan Tiga Bersaudara Berbasis Web telah selesai dibangun menggunakan bahasa pemrograman PHP dengan framework CodeIgniter, database MySql yang menggunakan metode waterfall sampai dengan tahap pengujian menggunakan blackbox. Pengujian menggunakan blackbox terhadap user dengan melibatkan 20 orang responden dapat disimpulkan bahwa aplikasi ini telah layak digunakan dan aplikasi berjalan dengan baik.
\end{abstract}

Kata Kunci : Aplikasi, Percetakan, Waterfall, Berbasis Web

Abstract: With the rapid development of technology and the increasing number of supporting facilities, people have started to use various services that are computerized because they are easier and there are many choices that can simplify all the needs that must be met and resolved. This study aims to build a web application. This application was built using the PHP programming language with the CodeIgniter framework, MYSQL database. The data collection technique instruments in this study were interviews, literature study, and observation. The software development method uses the waterfall method, namely software requirements analysis, design, programming, and testing. As well as the software testing method using black-box testing. The final result of this research is that the Web-based Three Brothers Printing Application has been completed using the PHP programming language with the CodeIgniter framework, the MySQL database using the waterfall method to the testing stage using the black box. Testing using a BlackBox on the user involving 20 respondents can be concluded that this application is feasible to use and the application runs well.

Keywords : Application, Printing, Waterfall, Based Web

\section{PENDAHULUAN}

\section{Latar Belakang}

Sejalan dengan perkembangan teknologi yang sangat pesat dan fasilitas-fasilitas pendukung yang semakin banyak, masyarakat mulai menggunakan berbagai layanan yang bersifat komputerisasi karena lebih mudah dan banyak pilihan yang dapat mempermudah segala kebutuhan yang harus dipenuhi dan diselesaikan. Hal ini dapat dilihat dari pemanfaatan teknologi informasi diberbagai bidang seperti bidang bisnis percetakan.

Tiga bersaudara merupakan nama percetakan yang terdapat di Kecamatan Narmada, Kabupaten Lombok Barat, Provinsi Nusa Tenggara Barat. Percetakan merupakan sebuah industri yang diperuntukkan untuk memproduksi tulisan ataupun gambar dengan memanfaatkan tinta melalui mesin cetak dengan jumlah yang sangat banyak. Percetakan menghasilkan sangat banyak produk seperti spanduk, kalender, undangan pernikahan, kartu nama, stempel dan lainnya. Hal ini membuat bisnis percetakan cepat sekali diminati banyak orang.

Percetakan tiga bersaudara mempromosikan produk yang dibuat secara manual yaitu dengan cara menyebarkan brosur ke sekitar lokasi daerah percetakan, dari mulut ke mulut, maupun pemasangan banner di depan tempat percetakan. Di dalam brosur maupun banner produk yang dipromosikan ke pelanggan masih tertulis secara garis besar dan belum secara keseluruhan tentang produk yang akan dibuat dari percetakan tersebut. Jadi apabila pelanggan ingin mengetahui atau menanyakan tentang produk yang lainnya, maka pelanggan harus berkunjung ke tempat percetakan atau bisa menghubungi pihak percetakan. Dengan demikian pelanggan akan menghabiskan waktu beserta tenaga untuk pergi ke lokasi percetakan tersebut.

Berdasarkan masalah yang telah dipaparkan di atas, penulis memanfaatkan teknologi berbasis web untuk merancang dan membangun aplikasi percetakan tiga bersaudara yang dapat memberikan informasi berupa lokasi percetakan, berbagai produk - produk beserta harga dari produk tersebut. Aplikasi berbasis web ini memudahkan pelanggan dalam mengakses semua informasi yang dikeluarkan oleh perusahaan atau pembisnis dan dapat diakses diberbagai perangkat kapan pun dan di mana pun.

Diharapkan dengan adanya aplikasi percetakan tiga bersaudara berbasis web ini dapat menjadi media promosi produk pada percetakan tiga bersaudara dan media untuk para pelanggan supaya mengetahui seluruh produk sehingga meningkatkan daya jumlah pembeli produk di percetakan tiga 
bersaudara dan langsung bisa bertanya atau konsultasi mengenai produk yang diinginkan.

\section{TINJAUAN PUSTAKA}

Beberapa penelitian memiliki kesamaan dan keterkaitan antara lain, yakni.

Petama penelitian yang dilakukan oleh Adi Supriyatna (2017) yang berjudul Sistem Informasi Pemesanan Jasa Percetakan Berbasis Web. Tujuan dari penelitian adalah untuk membangun sebuah sistem informasi berbasis web yang dapat mempermudah dan menghasilkan suatu perkembangan dalam hal produk yang diinginkan oleh konsumen serta dapat memberikan kemudahan kepada konsumen baik dalam hal mencari informasi detail produk maupun transaksi pemesanan untuk produk yang diinginkan[1].

Kedua penelitian yang dilakukan oleh Umi Salamah dan Herlawati (2018) yang berjudul Sistem Informasi Penjualan Barang Berbasis Web Pada Percetakan Rahayu Bekasi. Tujuan dari penelitian, yaitu: 1) Untuk memudahkan konsumen dalam melakukan pemesanan barang, maka penulis membuat sistem informasi penjualan barang pada percetakan berbasis web yang didalamnya terdapat fitur-fitur, fasilitas pemesanan disertai dengan cara pemesanannya. 2) Agar konsumen dapat dengan mudah dan lebih menghemat biaya, tenaga serta waktu dalam mendapatkan informasi mengenai barang, maka penulis membuat sistem informasi penjualan barang pada percetakan yang sederhana supaya mudah dimengerti dan mudah diakses kapan saja dan dimana saja [2].

Ketiga penelitian yang dilakukan oleh Rahmat Fauzi dkk (2018) yang berjudul Perancangan Aplikasi Marketplace Jasa Percetakan Berbasis Website $^{[3]}$. Tujuannya adalah diusulkan aplikasi marketplace jasa percetakan yang diberinama CETAKIN di mana dapat memberi beberapa nilai tambah seperti pencarian beberapa percetakan, melihat perbandingan harga antar percetakan, efisiensi waktu tanpa harus mengantri [3].

Keempat penelitian yang dilakukan oleh Ilyas (2013) yang berjudul Sistem Informasi Pencetakan Berbasis Web Pada Percetakan Ade Printing Tembilahan. Tujuan dari penelitian, yaitu: 1) Pelanggan bisa memperoleh informasi-informasi mengenai berbagai macam produk yang tersedia di Percetakan Ade Printing Tembilahan beserta harga yang ditawarkannya. 2) Memudahkan Admin (pihak Percetakan Ade Printing Tembilahan) dalam mendapatkan data diri Pelanggan dan data pesanannya. 3) Memudahkan Admin dalam pembuatan laporan transaksi yang akan diserahkan kepada Pimpinan [4].

Kelima penelitian yang dilakukan oleh Aryo Nur Utomo dan Muhammad Alfaridzi (2018) yang berjudul Perancangan Sistem Informasi Pada Percetakan CV Citra Kencana Jakarta Timur Berbasis Web. Penelitian ini bertujuan untuk mempermudah para konsumen untuk melakukan pemesanan untuk pencetakan di Percetakan Citra Kencana dengan cara membuat website pemesanan [5].

Dari penelitian - penelitian yang pernah dilakukan sebelumnya, persamaan dengan penelitian yang diteliti oleh penulis secara umum yaitu agar dapat dimanfaatkan sebagai media untuk para pelanggan supaya mengetahui seluruh produk yang terdapat di percetakan. Perbedaan dari penelitian - penelitian yang pernah dilakukan sebelumnya yaitu penelitian yang dilakukan penulis bisa berintegrasi dengan whatsapp maupun fitur yang terdapat di dalam aplikasi.

\section{Dasar Teori}

Adapun dasar teori yang mendukung dalam pembuatan laporan ini sebagai berikut:

\section{Unified Modelling Language (UML)}

UML adalah standar bahasa yang banyak digunakan di dunia industri untuk mendefinisikan requirement, membuat desain dan analisis, serta menggambarkan arsitektur dalam pemrograman berorientasi objek [6].

Dalam penelitian proposal skripsi ini penulis menggunakan 4 jenis diagram yaitu [7]:

\section{Use Case Diagram}

Use case diagram merupakan pemodelan untuk kelakukan (behavior) sistem informasi yang akan dibuat. Use case mendeskripsikan sebuah interaksi antara satu atau lebih aktor dengan sistem informasi yang akan dibuat.

\section{Diagram Aktivitas (Activity Diagram)}

Activity Diagram menggambarkan workflow (aliran kerja) atau aktivitas dari sebuah sistem atau proses bisnis.

3. Class Diagram (Diagram Kelas)

Merupakan hubungan antar kelas dan penjelasan detail tiap-tiap kelas di dalam model desain dari suatu sistem, juga memperlihatkan aturan-aturan dan tanggungan jawab entitas yang menentukan perilaku sistem.

\section{Sequence Diagram}

Sequence diagram adalah diagram yang dibuat untuk mengetahui alur dari interaksi antar objek dengan menggambarkan kelakuan objek pada usecase dengan mendeskripsikan waktu hidup objek dan pesan yang dikirimkan dan diterima antar objek.

\section{Percetakan}

Percetakan merupakan sebuah proses industri untuk memproduksi secara massal tulisan dan gambar. Perusahaan jasa percetakan adalah suatu usaha percetakan yang memproduksi berbagai macam media cetak diantaranya: banner, spanduk, undangan dan masih banyak yang lainnya [1]. 


\section{Metode Waterfall}

Model air terjun (waterfall) sering juga disebut model alur hidup klasik. Model waterfall menyediakan pendekataan alur hidup perangkat lunak secara terurut dimulai dari analisis, desain, pengkodean, pengujian dan tahap pendukung (support) [8]. Model waterfall adalah model klasik yang bersifat sistematis, berurutan dalam membangun software. metode waterfall dianggap pendekatan yang lebih cocok digunakan untuk proyek pembuatan sistem baru dan juga pengembangan software dengan tingkat resiko yang kecil serta waktu pengembangan yang cukup lama [9].

\section{Pengujian Blackbox}

Pengujian blackbox merupakan pengujian software dari segi spesifikasi fungsional tanpa menguji desain dan kode program. Pengujian yang artinya untuk mengetahui apakah fungsi-fungsi, masukan, dan keluaran dari perangkat lunak sesuai dengan spesifikasi yang dibutuhkan [10].

\section{Berbasis Web}

Web adalah layanan informasi dengan menghubungkan antar halaman (hyperlink). Konsep dari informasi dapat terdiri dari teks, gambar, animasi, suara maupun video [11].

Website adalah fasilitas internet yang menghubungkan dokumen dalam lingkup lokal maupun jarak jauh [12].

\section{METODE PENELITIAN}

Adapun alur dari penelitian " Rancang Bangun Aplikasi Percetakan Tiga Bersaudara Berbasis Web dengan Metode Waterfall'adalah sebagai berikut:

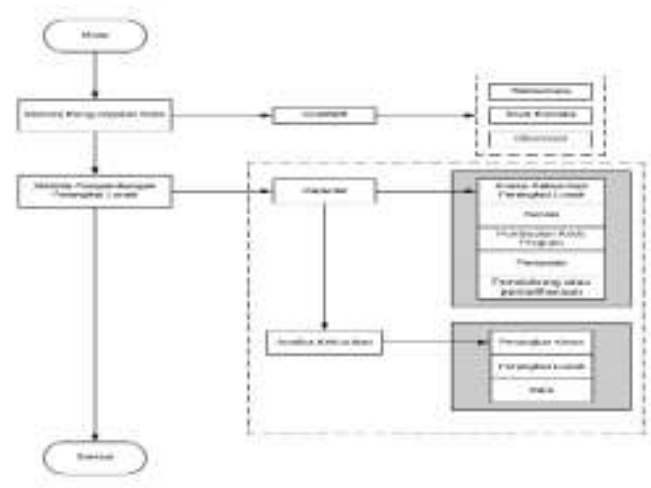

Gambar 1. Alur Metode Penelitian

\section{Metode Pengembangan Perangkat Lunak}

Metode pengembangan perangkat lunak yang diterapkan penulis dalam membangun aplikasi percetakan tiga bersaudara berbasis web adalah menggunakan metode waterfall karena dianggap pendekatan yang lebih cocok digunakan untuk proyek pembuatan sistem baru [9], berikut ini tahapan- tahapan dalam pengembangan perangkat lunak menggunakan model waterfall:

a. Analisis kebutuhan perangkat lunak

Pada tahap ini merupakan tahap awal di mana penelitian dimulai, adapun beberapa aktivitas yang dilakukan pada tahap ini yakni:

1. Melakukan wawancara kepada pihak percetakan dengan tujuan memperoleh sejumlah data untuk dianalisis dan untuk menemukan permasalahan yang ada sebagai kebutuhan pendukung penelitian.

2. Melakukan studi pustaka untuk mencari dan mempelajari pustaka yang ada sebagai bahan acuan dan pertimbangan dalam penelitian yang diperoleh dari pustaka-pustaka berupa jurnal dan internet yang terkait dengan penelitian.

3. Melakukan identifikasi batasan masalah untuk membatasi penyelesaian masalah sesuai dengan kemampuan penulis.

4. Melakukan analisa kebutuhan perangkat yang berupa kebutuhan perangkat keras dan kebutuhan perangkat lunak untuk pembuatan aplikasi Percetakan Tiga Bersaudara.

b. Desain

Tahap desain merupakan tahap kedua setelah tahap analisis kebutuhan perangkat lunak pada tahap ini diantaranya:

1. Melakukan perancangan dengan UML diantaranya:

a. Merancang use case sebagai gambaran dari aplikasi yang akan dibangun.

b. Melakukan perancangan activity diagram untuk deskripsi ativitas setiap use case.

c. Melakukan perancangan sequence diagram untuk menggambarkan alur interaksi antar pengguna dalam aplikasi.

d. Melakukan perancangan class diagram untuk kepentingan database.

2. Melakukan perancangan desain antarmuka (interface) aplikasi.

\section{c. Pembuatan kode program}

Tahap ini merupakan proses puncak dalam pembuatan aplikasi, yaitu merupakan proses penciptaan sebuah aplikasi yang berkesesuaian dengan apa yang telah dilakukan pada tahap perencanaan, analisa dan desain sistem di percetakan tiga bersaudara. Penulis selanjutnya akan melakukan penulisan kode program dengan menggunakan bahasa pemrograman PHP menggunakan framework codeigniter.

\section{d. Pengujian}

Tahap ini adalah tahap pengujian dan tahap pendukung yang artinya aplikasi yang telah dibuat dari hasil analisis masalah yang telah melalui tahaptahap desain, penulisan kode program barulah masuk ke dalam pengujian program, sehingga akan dapat diketahui seperti apa hasil kinerja aplikasi 
tersebut, kemudian dapat diketahui pula apakah aplikasi yang telah dibuat berjalan dengan baik sesuai dengan apa yang diharapkan di percetakan tiga bersaudara. Pada langkah pengujian program ini, penulis akan melakukan pengujian dengan menggunakan metode blackbox testing.

\section{Alat dan Bahan Penelitian}

Adapun alat dan bahan yang dibutuhkan dalam penelitian yaitu, kebutuhan perangkat dan kebutuhan data. Kebutuhan perangkat yang digunakan berupa perangkat keras (hardware) dan perangkat lunak (software. Sedangkan untuk kebutuhan data yang digunakan berupa semua produk beserta harga dari masing-masing produk yang terdapat di percetakan tiga bersaudara.

\section{HASIL DAN PEMBAHASAN}

\section{Perancangan Sistem}

Dalam perancangan sistem ini, peneliti menggunakan UML yaitu Use Case Diagram, Activity Diagram, Squence Diagram dan Class Diagram. Untuk lebih detailnya adalah sebagai berikut:

\section{a. Use Case}

Use case diagram menjelaskan mengenai hubungan antara actor (pengguna sistem) dengan proses-proses atau aktivitas pada perangkat lunak yang dibangun. Use case diagram dari aplikasi percetakan tiga bersaudara berbasis web adalah sebagai berikut.

\section{Use case diagram admin.}

Berikut ini merupakan use case diagram admin pada aplikasi percetakan tiga bersaudara berbasis web.

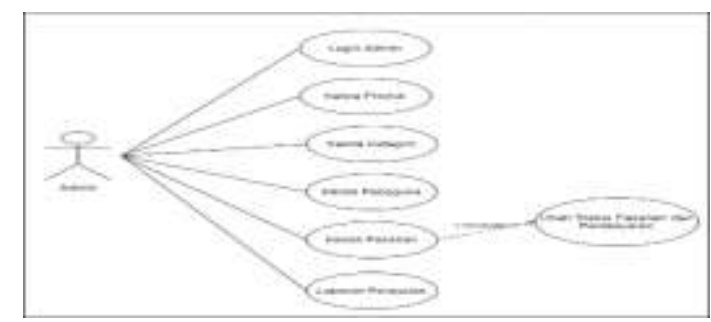

Gambar 2. Use Case Diagram Admin

Gambar di atas mendeskripsikan bahwa admin dapat melakukan login sebagai admin, kelola produk, kelola kategori produk, kelola pengguna (pelanggan), kelola pesanan pelanggan dan juga dapat melihat laporan penjualan.

b. Use case diagram pelanggan.
Berikut ini merupakan use case diagram pelanggan pada aplikasi percetakan tiga bersaudara berbasis web.

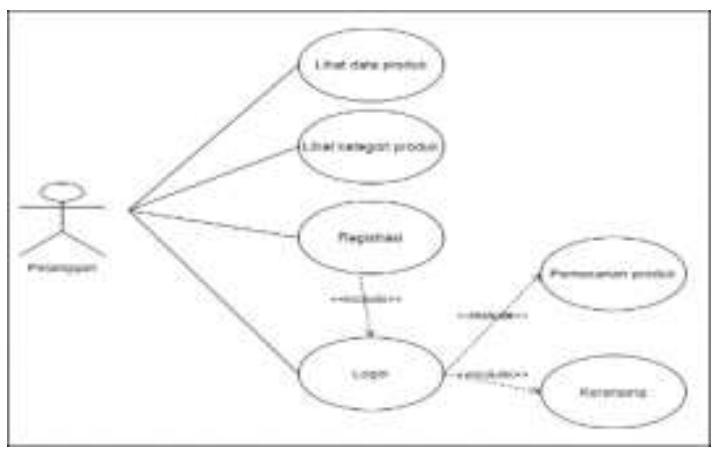

Gambar 3. Use Case Diagram Pelanggan

Gambar di atas mendeskripsikan bahwa pelanggan dapat melihat data produk dan kategori produk. Pelanggan bisa melakukan registrasi untuk dapat login ke dalam aplikasi agar dapat melakukan pemesanan produk dan melihat keranjang pemesanan.

\section{b. Activity Diagram}

Activity diagram menjelaskan mengenai alur aktivitas-aktivitas yang terjadi dalam aplikasi yang dibangun. Activity diagram aplikasi percetakan tiga bersaudara berbasis $w e b$ adalah sebagai berikut.

\section{Activity diagram login pelanggan/user.}

Berikut ini merupakan activity diagram login pelanggan pada aplikasi percetakan tiga bersaudara berbasis web.

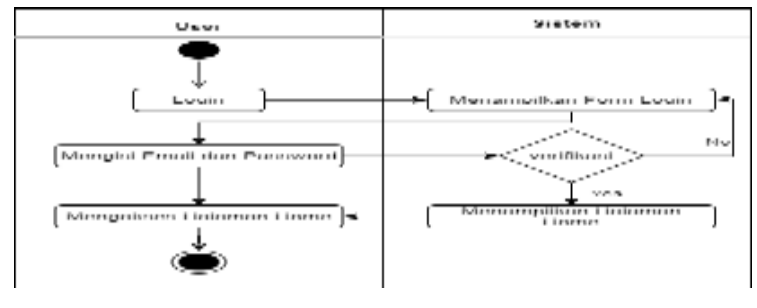

Gambar 4. Activity diagram login pelanggan/user

\section{Activity Diagram Registrasi Pelanggan/User.}

Berikut ini merupakan activity diagram registrasi pelanggan pada aplikasi percetakan tiga bersaudara berbasis web.

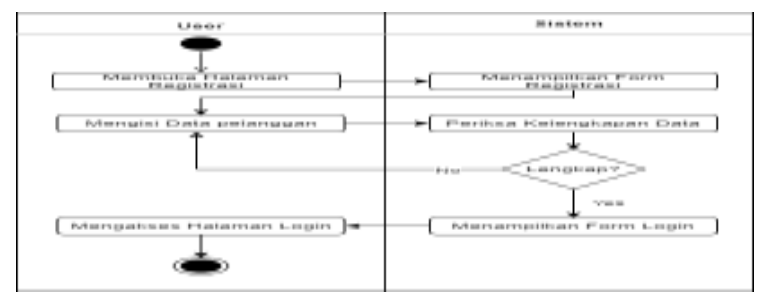

Gambar 5. Activity Diagram Registrasi User

3. Activity Diagram Lihat Produk. 
Berikut ini merupakan activity diagram lihat produk pada aplikasi percetakan tiga bersaudara berbasis web.

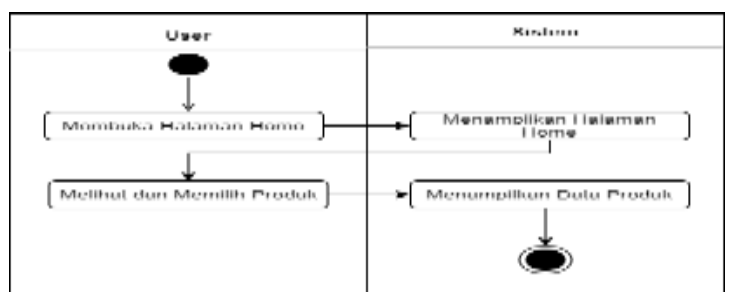

Gambar 6. Activity Diagram Lihat Produk

4. Activity Diagram Pemesanan Produk.

Berikut ini merupakan activity diagram pemesanan produk pada aplikasi percetakan tiga bersaudara berbasis web.

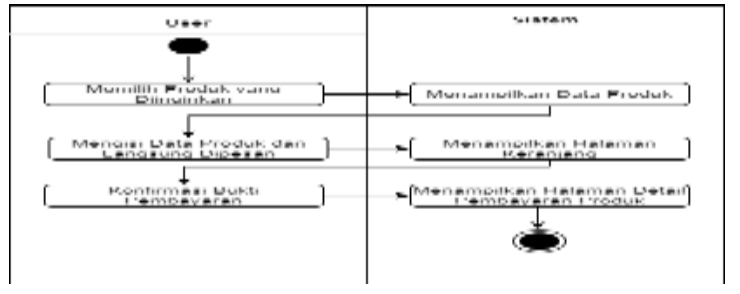

Gambar 7. Activity Diagram Pemesanan Produk

\section{Activity Diagram Keranjang.}

Berikut ini merupakan activity diagram keranjang pada aplikasi percetakan tiga bersaudara berbasis web.

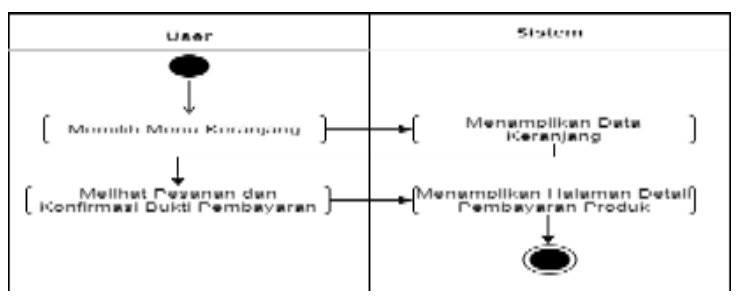

Gambar 8. Activity Diagram Keranjang

\section{c. Sequence Diagram}

Sequence diagram menggambarkan bagaimana interaksi antara objek yang terdapat dalam aplikasi. Sequence diagram dari aplikasi percetakan tiga bersaudara berbasis web adalah sebagai berikut.

1. Sequence Diagram Login Pelanggan/User.

Berikut ini merupakan sequence diagram login pelanggan pada aplikasi percetakan tiga bersaudara berbasis web.

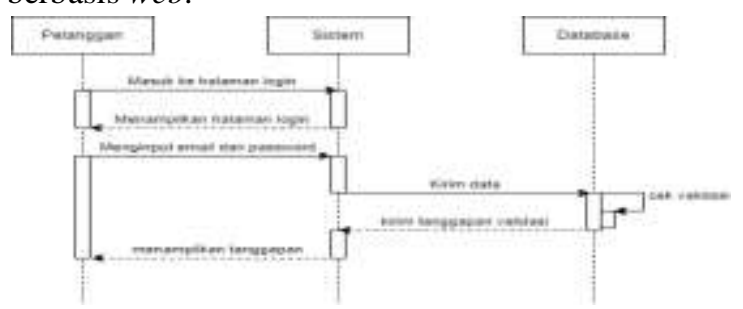

Gambar 9. Sequence Diagram Login User

\section{Sequence Diagram Registrasi.}

Berikut ini merupakan sequence diagram registrasi pada aplikasi percetakan tiga bersaudara berbasis web.

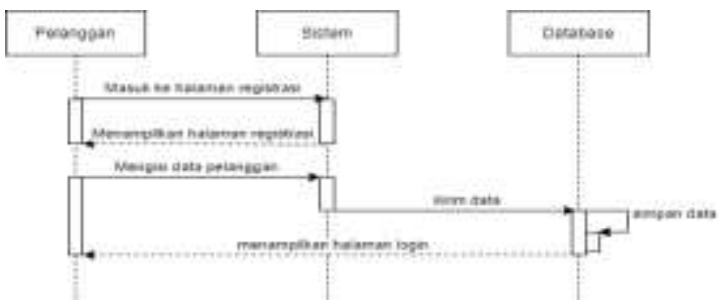

Gambar 10. Sequence Diagram Registrasi

3. Sequence Diagram Lihat Produk.

Berikut ini merupakan sequence diagram lihat produk pada aplikasi percetakan tiga bersaudara berbasis web.

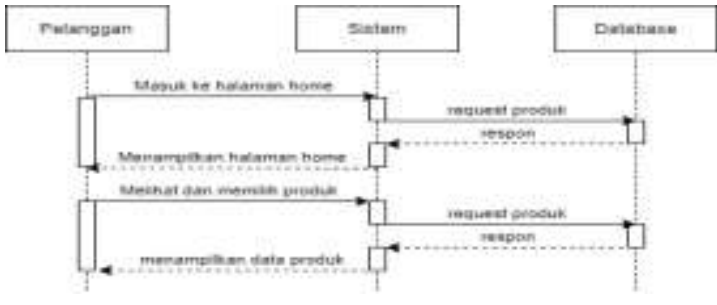

Gambar 11. Sequence Diagram Lihat Produk

4. Sequence Diagram Pemesanan Produk.

Berikut ini merupakan sequence diagram pemesanan produk pada aplikasi percetakan tiga bersaudara berbasis web.

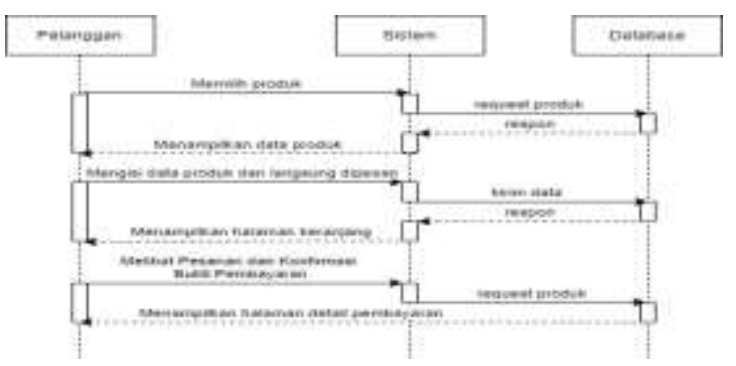

Gambar 12. Sequence Diagram Pemesanan Produk

\section{Sequence Diagram Keranjang.}

Berikut ini merupakan sequence diagram keranjang pada aplikasi percetakan tiga bersaudara berbasis web.

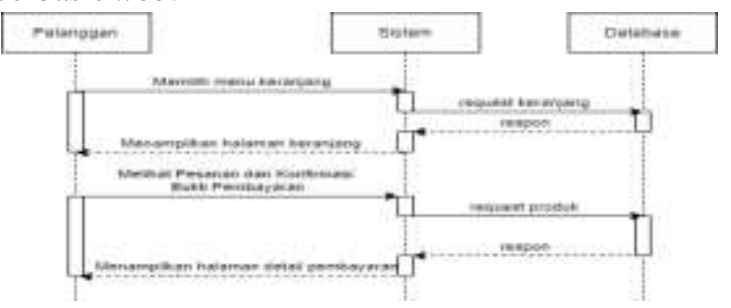

Gambar 13. Sequence Diagram Keranjang

\section{d. Class Diagram}

Rancangan class diagram merupakan deskripsi dari interaksi tiap-tiap class yang saling terhubung. 
Berikut ini merupakan rancangan class diagram pada aplikasi percetakan tiga bersaudara.

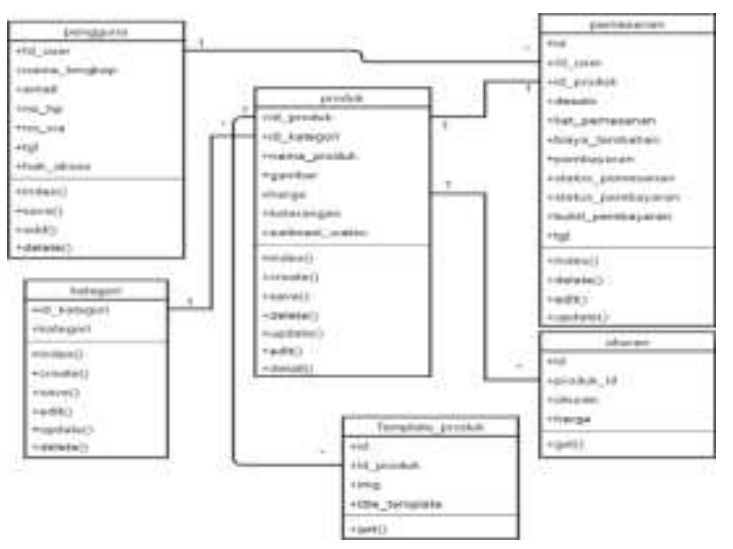

Gambar 14. Class Diagram

e. Rancangan Interface

1. Rancangan Halaman Utama.

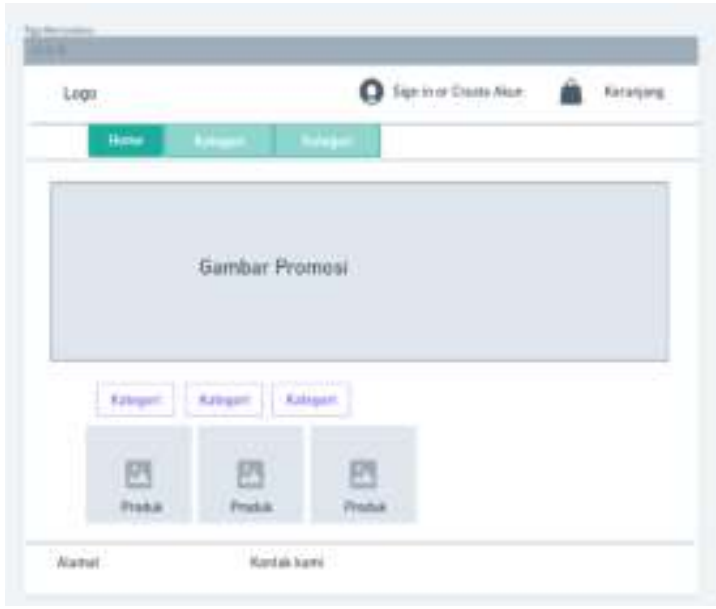

Gambar 15. Rancangan Halaman Utama

Gambar di atas merupakan rancangan tampilan halaman utama, halaman ini menampilkan semua produk dan kategori produk yang ada di percetakan tiga bersaudara.

2. Rancangan Halaman Admin Kelola Produk.

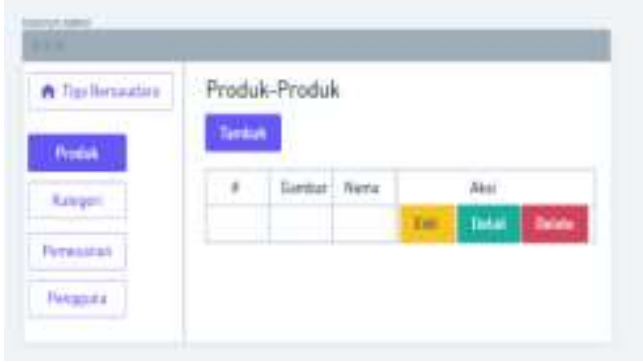

Gambar 16. Rancangan Halaman Admin Kelola Produk

Gambar di atas merupakan rancangan tampilan halaman admin kelola produk, halaman ini menampilkan produk serta apa saja yang bisa dilakukan oleh admin seperti tombol tambah produk, edit produk, detail produk dan hapus produk.

2. Implemntasi dan Pengujian

a. Tampilan Halaman Utama

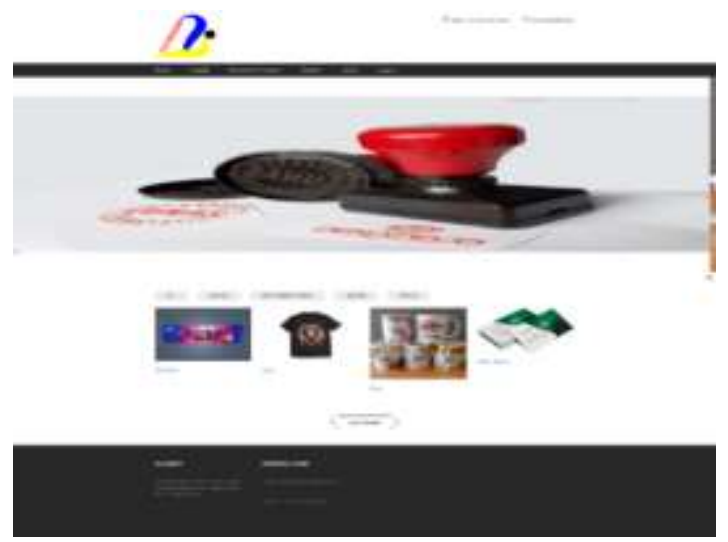

Gambar 17. Tampilan Halaman Utama

Gambar di atas merupakan tampilan halaman utama, halaman ini menampilkan semua produk dan kategori produk yang ada di percetakan tiga bersaudara.

b. Tampilan Halaman Admin Kelola Produk

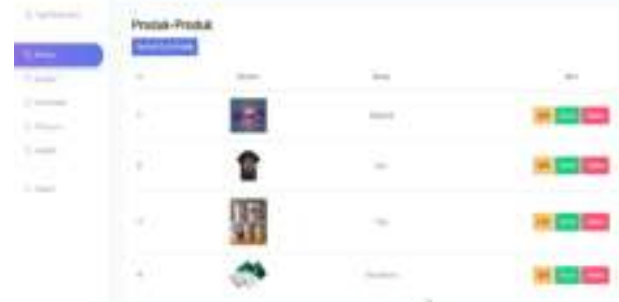

Gambar 18. Tampilan Halaman Admin Kelola Produk

Gambar di atas merupakan rancangan tampilan halaman admin kelola produk, halaman ini menampilkan produk serta apa saja yang bisa dilakukan oleh admin seperti tombol tambah produk, edit produk, detail produk dan hapus produk.

c. Pengujian Sistem

Adapun hasil pengujian dari Aplikasi Percetakan Tiga Bersaudara Berbasis Web dengan melibatkan 20 responden yaitu 1 orang dari pihak Percetakan Tiga Bersaudara dan 19 orang calon pelanggan adalah sebagai berikut.

1. Pertanyaan pertama tentang tampilan web tiga bersaudara yaitu sebanyak 14 responden mengatakan sudah sesuai dan menarik sedangan 6 responden mengatakan masih belum sesuai.

2. Pertanyaan kedua tentang fitur aplikasi tiga bersaudara yaitu sebanyak 20 responden mengatakan fitur sudah berjalan dengan baik. 
3. Pertanyaan ketiga tentang warna dan tata letak teks aplikasi tiga bersaudara yaitu sebanyak 13 responden mengatakan sudah bagus sedangkan 7 responden mengatakan masih kurang menarik.

4. Pertanyaan keempat tentang pengoperasian aplikasi tiga bersaudara yaitu sebanyak 15 responden mengatakan mudah digunakan sedangkan 5 responden mengatakan sulit digunakan.

5. Pertanyaan kelima tentang struktur menu aplikasi tiga bersaudara yaitu sebanyak 16 responden mengatakan sudah bagus sedangakan 4 responden mengatakan kurang menarik.

e. Pengujian Admin Kelola Produk.

Tabel 1. Pengujian Admin Kelola Produk

\begin{tabular}{|c|c|c|c|}
\hline $\begin{array}{l}\mathrm{N} \\
\mathrm{O}\end{array}$ & $\begin{array}{c}\text { Skenario } \\
\text { Pengujian }\end{array}$ & $\begin{array}{l}\text { Hasil Yang } \\
\text { diharapkan }\end{array}$ & Kesimpulan \\
\hline 1 & $\begin{array}{l}\text { Mengisi form } \\
\text { untuk } \\
\text { menambahkan } \\
\text { produk baru }\end{array}$ & $\begin{array}{l}\text { Menampilka } \\
\text { n pesan } \\
\text { "produk } \\
\text { berhasil } \\
\text { ditambahkan } \\
\text { "jika produk } \\
\text { berhasil } \\
\text { ditambah }\end{array}$ & Sesuai \\
\hline 2 & \begin{tabular}{lr}
\multicolumn{2}{l}{ Mengubah } \\
data & produk \\
yang & sudah \\
ada &
\end{tabular} & $\begin{array}{l}\text { Menampilka } \\
\text { n pesan } \\
\text { "produk } \\
\text { berhasil } \\
\text { diubah" jika } \\
\text { produk } \\
\text { berhasil } \\
\text { diubah }\end{array}$ & Sesuai \\
\hline 3 & $\begin{array}{l}\text { Memilih } \\
\text { tombol detail } \\
\text { pada salah satu } \\
\text { produk }\end{array}$ & $\begin{array}{l}\text { Menampilka } \\
\mathrm{n} \text { halaman } \\
\text { detail produk } \\
\text { yang dipilih }\end{array}$ & Sesuai \\
\hline 4 & $\begin{array}{l}\text { Memilih salah } \\
\text { satu produk } \\
\text { untuk dihapus } \\
\text { dan tekan } \\
\text { tombol OK }\end{array}$ & $\begin{array}{l}\text { Menampilka } \\
\text { n pesan } \\
\text { "Apakah } \\
\text { anda yakin?" } \\
\text { dan kembali } \\
\text { ke halaman } \\
\text { admin } \\
\text { produk } \\
\text { ketika } \\
\text { produk telah } \\
\text { dihapus }\end{array}$ & Sesuai \\
\hline
\end{tabular}

f. Pengujian Pemesanan Produk dan Keranjang
Tabel 2. Pengujian Pemesanan Produk Dan Keranjang

\begin{tabular}{|c|c|c|c|}
\hline No & $\begin{array}{l}\text { Skenario } \\
\text { Pengujian }\end{array}$ & $\begin{array}{l}\text { Hasil Yang } \\
\text { diharapkan }\end{array}$ & Kesimpulan \\
\hline 1 & $\begin{array}{l}\text { Pelanggan } \\
\text { memesan } \\
\text { produk } \\
\text { yang } \\
\text { diinginkan } \\
\text { dengan klik } \\
\text { tombol } \\
\text { Shop Now }\end{array}$ & $\begin{array}{l}\text { Sistem akan } \\
\text { menampilkan } \\
\text { halaman } \\
\text { keranjang }\end{array}$ & Sesuai \\
\hline 2 & $\begin{array}{l}\text { Pelanggan } \\
\text { memilih } \\
\text { menu } \\
\text { keranjang }\end{array}$ & $\begin{array}{l}\text { Masuk ke } \\
\text { halaman } \\
\text { keranjang dan } \\
\text { menampilkan } \\
\text { informasi } \\
\text { pesanan } \\
\text { pelanggan }\end{array}$ & Sesuai \\
\hline 3 & $\begin{array}{l}\text { Pelanggan } \\
\text { memilih } \\
\text { menu } \\
\text { keranjang } \\
\text { dan } \\
\text { mengklik } \\
\text { button } \\
\text { upload } \\
\text { bukti }\end{array}$ & $\begin{array}{l}\text { Masuk ke } \\
\text { halaman detail } \\
\text { pembayaran } \\
\text { dan } \\
\text { menampilkan } \\
\text { informasi } \\
\text { pemesanan } \\
\text { serta } \\
\text { informasi } \\
\text { harga yang } \\
\text { harus dibayar }\end{array}$ & Sesuai \\
\hline 4 & $\begin{array}{l}\text { Pelanggan } \\
\text { memilih } \\
\text { menu } \\
\text { keranjang } \\
\text { dan } \\
\text { menghapus } \\
\text { pesanan }\end{array}$ & $\begin{array}{l}\text { Menampilkan } \\
\text { pesan } \\
\text { "Apakah anda } \\
\text { yakin?" dan } \\
\text { kembali ke } \\
\text { halaman } \\
\text { keranjang } \\
\text { ketika pesanan } \\
\text { telah dihapus }\end{array}$ & Sesuai \\
\hline
\end{tabular}

\section{KESIMPULAN DAN SARAN}

\section{Kesimpulan}

Dari hasil analisis dan perancangan sistem yang telah dilakukan sebelumnya, maka penulis dapat mengambil kesimpulan bahwa aplikasi Percetakan Tiga Bersaudara Berbasis Web telah selesai dibangun menggunakan bahasa pemrogramman $P H P$ dengan framework CodeIgniter, database MySql yang menggunaan metode waterfall sampai dengan tahap pengujian menggunakan blackbox. Pengujian menggunkan blackbox terhadap user dengan melibatkan 20 orang responden dapat disimpulkan bahwa aplikasi ini telah layak digunakan dan aplikasi berjalan dengan baik. 
Berdasarkan kesimpulan yang telah diuraikan diatas, aplikasi yang telah dibuat masih jauh dari kesempurnaan. Maka penulis memberikan saran untuk pengembang aplikasi ini kedepannya yaitu menambahkan fitur transaksi pembayaran secara online, memperbagus tampilan aplikasi agar lebih menarik, menambah fitur notifikasi untuk promo produk terbaru maupun diskon produk dan memperlengkap rincian dari produk.

\section{DAFTAR PUSTAKA}

[1] A. Supriyatna, "SISTEM INFORMASI PEMESANAN JASA PERCETAKAN BERBASIS WEB," SWABUMI, vol. 5, hal. 65, 2017.

[2] U. Salamah dan Herlawati, "Sistem Informasi Penjualan Barang Berbasis Web Pada Percetakan Rahayu Bekasi,” J. Penelit. Ilmu Komputer, Syst. Embed. Log., vol. 6, no. 1, hal. 61-74, 2018.

[3] R. Fauzi, S. Wibowo, dan D. Y. Putri, "Perancangan Aplikasi Marketplace Jasa Percetakan Berbasis Website," Fountain Informatics J., vol. 3, no. 1, hal. 5-11, 2018.

[4] Ilyas, "Sistem Informasi Pencetakan Berbasis Web Pada Percetakan Ade Printing Tembilahan," J. Sist., vol. 2, no. 3, hal. 1-14, 2013

[5] A. N. Utomo dan M. Alfaridzi, "Perancangan Sistem Informasi Pada Percetakan Cv Citra Kencana Jakarta Timur Berbasis Web," J. Rekayasa Inf., vol. 7, no. 1, hal. 43-47, 2018.

[6] D. W. T. Putra dan R. Andriani, "Unified Modelling Language ( UML ) dalam Perancangan Sistem Informasi Permohonan Pembayaran Restitusi SPPD," J. TEKNOIF, vol. 7, no. 1, hal. 33, 2019.

[7] G. Urva dan H. F. Siregar, "Pemodelan UML EMarketing Minyak Goreng," J. Teknol. dan Sist. Inf., vol. 1, no. 2, hal. 94-95, 2015.

[8] R. A. S dan M. Shalahuddin, Rekayasa Perangkat Lunak Terstruktur dan Berorientasi Objek, Ke-3. Bandung: Informatika Bandung, 2015.

[9] N. A. Gayatri, Nawassyarif, W. Ismiyarti, S. Khair, dan Muti'ah, "SISTEM INFORMASI PENDATAAN DAN PENGARSIPAN BERKAS PELAYANAN ADMINISTRASI TERPADU KECAMATAN (PATEN) DI KECAMATAN SUMBAWA DENGAN METODE WATERFALL," JINTEKS (Jurnal Inform. Teknol. dan Sains), vol. 3 , no. 1, hal. 303, 2021.

[10] Y. A. Pratama dan E. Junianto, "Sistem Pakar Diagnosa Penyakit Ginjal Dan Saluran Kemih Dengan Metode Breadth First Search," J. Inform., vol. 2, no. 1, hal. 218, 2015.

[11] C. A. Pamungkas dan Sudarmaji, "RANCANG BANGUN E-LEARNING CENTER BERBASIS WEB UNTUK MENINGKATKAN KUALITAS DAN KUANTITAS MEDIA PEMBELAJARAN YANG EFEKTIF," J. Inf. Politek. Indonusa Surakarta, vol. 1, no. 2, hal. 9-10, 2015.

[12] Nawassyarif, M. Julkarnain, dan K. Rizki Ananda, "Sistem Informasi Pengolahan Data Ternak Unit Pelaksana Teknis Produksi Dan Kesehatan Hewan Berbasis Web," J. Inform. Teknol. dan Sains, vol. 2, no. 1, hal. 34, 2020. 